\title{
Influence of Cooling on the Glycolysis Rate and Development of PSE (Pale, Soft, Exudative) Meat
}

\author{
Mayka Reghiany Pedrão ${ }^{1 *}$, Talita Kato ${ }^{1}$, Adriana Lourenço Soares ${ }^{2}$, Elza Iouko Ida ${ }^{2}$, \\ Fábio Augusto Garcia Coró ${ }^{1}$, Moises Grespan $^{1}$, Fernanda Paião ${ }^{1}$ and Massami \\ Shimokomaki ${ }^{1,2}$ \\ ${ }^{1}$ Universidade Tecnológica Federal do Paraná; Londrina - PR - Brasil. ${ }^{2}$ Departamento de Ciência e Tecnologia de \\ Alimentos ; Universidade Estadual de Londrina; Londrina - PR - Brasil
}

\begin{abstract}
The aim of this work was to evaluate $p H$ values fall rate in chicken breast meat under commercial refrigeration processing conditions and the development of PSE (pale, soft, exudative) meat. Broiler breast samples from the Cobb breed, both genders, at 47 days of age $(n=100)$ were taken from refrigerated carcasses $(R S)$ immersed in water and ice in a tank chilled at $0^{\circ} \mathrm{C}( \pm 2) . p H$ and temperature $(T)$ values were recorded at several periods throughout refrigeration in comparison to samples left at room $T$ as control (CS). The ultimate pH (pHu) value of 5.86 for $R S$ carcasses were only reached at $11^{\circ} \mathrm{C}$ after $8.35 \mathrm{~h}$ post mortem (PM) while, for CS samples, pHu value was 5.94 at $22^{\circ} \mathrm{C}$ after $4.08 \mathrm{~h}$ PM. Thus, under commercial refrigeration conditions, the glycolysis rate was retarded by over $4.0 \mathrm{~h}$ PM and the breast meat color was affected. At $24.02 \mathrm{~h}$ PM, PSE meat incidence was $30 \%$ while for CS, meat remained dark and PSE meat was not detected. Results show retardation in the glycolysis rate and PSE meat development was promoted by the refrigeration treatment when compared with samples stored at processing room temperature.
\end{abstract}

Key words: post mortem management, commercial processing refrigeration, water chiller

\section{INTRODUCTION}

Brazil has become the third largest producer and the world's largest exporter of chicken meat, with an annual production of 12.65 million tons and exports of 3.9 million tons in 2012 (UBABEF 2013). However, the development of PSE (pale, soft, exudative) meat has brought problems to the poultry meat-processing industry, and PSE is estimated to generate costs in the poultry industry of over US \$200 million in the USA and over US $\$ 36$ million in Brazil yearly (Oda et al. 2003; Owens 2009). Therefore, besides the economical need to overcome these problems, a proper management system to promote the welfare of these birds and to prevent stressful conditions that can lead to the development of meat color have become great challenges to the meat industry (Olivo et al. 2001; Barbut et al. 2008; Simões et al. 2009a, 2009b; Langer et al. 2010; Barbosa et al. 2013). PSE meat originates from a rapid decline in $\mathrm{pH}$ while the muscle is still warm during the completion of glycolysis, leading to the denaturation of myofibril proteins thus compromising their functional properties (Sosnicki et al.1998; Olivo et al. 2001) although, as in pigs, there are possible genetic connotations/implications (Paião et al. 2013). In addition, Droval et al. (2012) have recently reported that consumers can detect breast fillet meat color abnormality visually at the point of purchase and odd flavors after cooking it. In

*Author for correspondence: maykapedrao@utfpr.edu.br 
general, carcass cooling immersion applied by Brazilian companies consists of continuous passages in tanks (chillers) that contain cold water and ice. Brazilian legislation establishes the use of at least two cooling tanks in sequence, being the first the maximum temperature at $16.0 \pm 5^{\circ} \mathrm{C}$ and the second at $4.0 \pm 5^{\circ} \mathrm{C}$, respectively. The immediate cooling of carcasses after slaughtering and evisceration are requirements set by Ordinance 210/98 - MAPA (Ministry of Agriculture, Livestock and Supply) and they require that the maximum temperature of the carcass at the second chiller exit should be at $7.0 \pm$ $5^{\circ} \mathrm{C}$. For the carcass to be immediately frozen, in a sequence, this limit is $10.0 \pm 5^{\circ} \mathrm{C}$ (Brasil 1998). Although various reports have been dealing with the interrelationships between $\mathrm{pH}$ fall and post mortem temperature storage (Alvarado and Sams 2004; James et al. 2006), in loco experiments at the commercial refrigerated processing line are still needed in order to effectively inhibit the development of color abnormality thus improving chicken meat quality directly for the consumers. The objective of the chilling process is mostly to inhibit the growth of dangerous pathogenic microorganisms and the air-chilling technique is frequently applied in Europe whereas immersion chilling is generally preferred in Brazil.

Therefore, the aim of this work was to evaluate the establishment of glycolysis in chicken breast meat in loco i.e. under commercial slaughterhouse processing line conditions and to verify the formation of PSE meat throughout rigor mortis installation.

\section{MATERIAL AND METHODS}

\section{Sampling and refrigeration systems}

This experiment was conducted in the spring of 2013, under commercial processing plant conditions, in the state of Paraná, Brazil. Cobb lineage birds $(n=100$ for each treatment), both genders, and at 47 days of age, were sacrificed according to industrial slaughtering routine practices as shown in Figure 1: suspended by shackles, electric stunning, bleeding, scalding, defeathering, evisceration, chilling, deboning and storing in a cold room. In addition, in Figure 1 is shown the actual location of samples for collection for temperature $(\mathrm{T}), \mathrm{pH}$ and color $\left(\mathrm{L}^{*}\right)$ evaluation. For control samples (CS), eight periods of measurement were taken and seven periods of measurement were performed on refrigerated samples (RS). CS were left at processing room temperature, starting from $30.55^{\circ} \mathrm{C}$ ending up to $21.85^{\circ} \mathrm{C}$ after $24.02 \mathrm{~h}$ of storage. RS group samples started the $\mathrm{T}$ value of $34.82^{\circ} \mathrm{C}$ and final $\mathrm{T}$ value was $7.54^{\circ} \mathrm{C}$ under immersion treatment. Time for each carcass to travel inside the chiller was $1.05 \mathrm{~h}$. Thus, the first location of samples taken was after $0.18 \mathrm{~h}$ post mortem (PM) and the last after $24.02 \mathrm{~h} \mathrm{PM}$, for both treatments. The RS group followed the usual slaughtering process, with cooling in ice water tanks at $0{ }^{\circ} \mathrm{C}$. Samples were collected after evisceration and measurements were performed accordingly. Finally, samples were stored in a cold room $\left(4^{\circ} \mathrm{C}\right)$ until the last measurement at $24.02 \mathrm{~h}$ of storage.

\section{pH, temperature and color determination}

Temperature and $\mathrm{pH}$ values were recorded (in duplicate) by inserting electrodes into the breast muscle, pectoralis major $m$., using the $\mathrm{pH}$ meter system (Testo 205). The Minolta CR400 colorimeter was used to evaluate color, $\mathrm{L}^{*}$ (lightness), on the posterior surface of the intact skinless at three different sites of the same sample as described in Olivo et al. (2001). PSE or Normal meat classification was determined by the $\mathrm{pH}$ value and lightness $\left(\mathrm{L}^{*}\right)$ and $\mathrm{pH}$ values $\leq 5.8$ and $\mathrm{L}^{*} \geq 53$, as PSE and $\mathrm{pH}>5.8$ e $44<\mathrm{L}^{*}<53$ were considered Normal, as described in Soares et al. (2003).

\section{Statistical analysis}

The statistical results analysis was performed using the Statistica program for Windows 10.0. The Tukey test at $5 \%$ of probability $(\mathrm{p}<0.05)$ was used to determine significant difference for measurement period, for each treatment. The Student t-test at $5 \%$ probability $(\mathrm{p}<0.05)$ was used to determine significant difference between two treatments, CS and RS, in the period of $24.02 \mathrm{~h}$ PM. Data from the last measurement $(24.02 \mathrm{~h})$ were analyzed by the Chi square test $\left(\chi^{2}\right)$ at $5 \%$ of probability $(\mathrm{p}<0.05)$. 


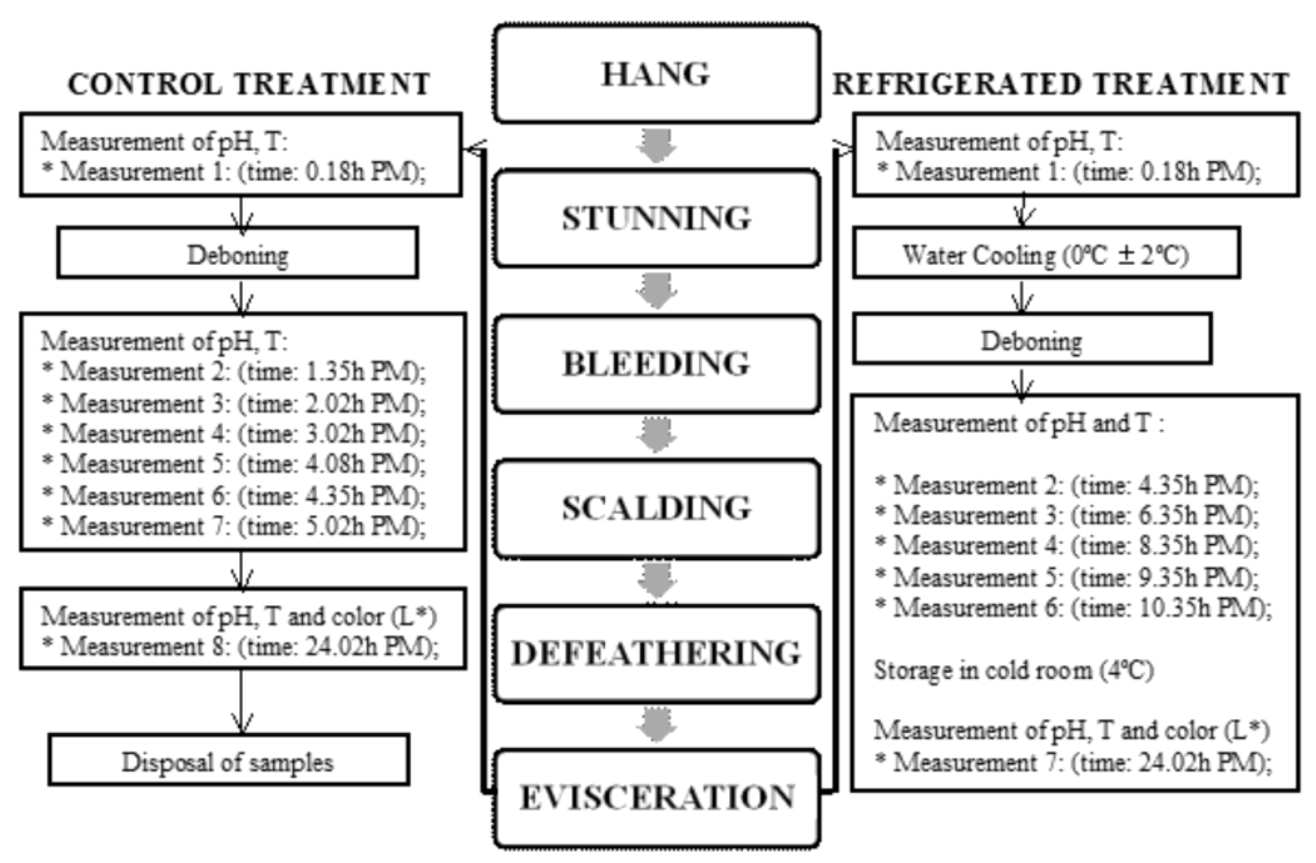

Figure 1 - Flowchart showing a slaughterhouse typical processing line for breast chicken in Brazil and the location where samples were taken for analysis. After evisceration, the first measurement was performed for $\mathrm{pH}$ and $\mathrm{T}$ determination at $0.18 \mathrm{~h} \mathrm{PM}$ until reaching the last measurement at $24.02 \mathrm{~h}$ PM for control and refrigerated treatment.

* PM: Post Mortem; T: temperature

\section{RESULTS}

The results on changes in $\mathrm{pH}$ and temperature values, as the chicken carcasses gradually became chilled in comparison to CS are demonstrated in Figures 2 and 3, respectively. At refrigerated conditions, at $0.18 \mathrm{~h} \mathrm{PM}$ the carcass $\mathrm{T}$ was $34.82^{\circ} \mathrm{C}$ \pm 2.46 while the $\mathrm{pH}$ value was 6.33 before the chiller tank treatment. The second measurement onward was carried out after $4.35 \mathrm{~h} \mathrm{PM}$ when the carcasses were immersed in a water/iced chiller tank at $0^{\circ} \mathrm{C} \pm 2$, when its $\mathrm{T}$ reached the value of $6.70^{\circ} \mathrm{C} \pm 1.22$ and the $\mathrm{pH}$ value measured was 6.06. Sequentially, at $6.35 \mathrm{~h} \mathrm{PM}$, the $\mathrm{pH}$ value was 5.92 and the $\mathrm{T}$ value was $9.76^{\circ} \mathrm{C} \pm 0.73$, while at $8.35 \mathrm{~h} \mathrm{PM}$ the $\mathrm{T}$ value was $10.98^{\circ} \mathrm{C} \pm 0.42$ reaching pHu of 5.86 up to the last measurement. As expected, these results were different from those found in CS group which started with $\mathrm{T}$ value of $30.55^{\circ} \mathrm{C} \pm 2.56$ and a $\mathrm{pH}$ of 6.40 . In this treatment, $\mathrm{pHu}$ of 5.94 was reached after $4.08 \mathrm{~h}$ $\mathrm{PM}$ under the $\mathrm{T}$ value of $22.43^{\circ} \mathrm{C} \pm 0.35$, showing no significant difference in relation to the last measurement at $24.02 \mathrm{~h}$ under $\mathrm{T}$ value of $21.85^{\circ} \mathrm{C}$ \pm 0.98 .

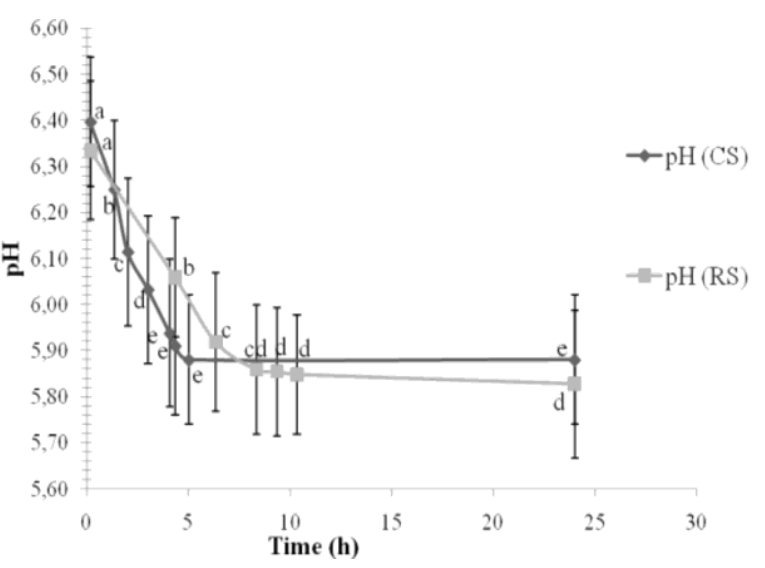

Figure 2 - The glycolysis profile of pectoralis $\mathrm{m}$. from broiler chicken with the $\mathrm{pH}$ measured firstly in the carcass subsequently in the breast meat samples held at $0.18 \mathrm{~h}, 1.35 \mathrm{~h}, 2.02 \mathrm{~h}$, $3.02 \mathrm{~h}, 4.08 \mathrm{~h}, 4.35 \mathrm{~h}, 5.02 \mathrm{~h}$ and $24.02 \mathrm{~h}$ PM aging in control samples (CS) and at $0.18 \mathrm{~h}, 4.35 \mathrm{~h}, 6.35 \mathrm{~h}, 8.35 \mathrm{~h}, 9.35 \mathrm{~h}, 10.35 \mathrm{~h}$ and $24.02 \mathrm{~h}$ aging in refrigerated samples (RS). Means ( $\mathrm{n}=100)$. ${ }^{\mathrm{a}-\mathrm{e}}$ significant different by Tukey test $(\mathrm{p}<0.05)$ among post mortem time in the same treatment. 


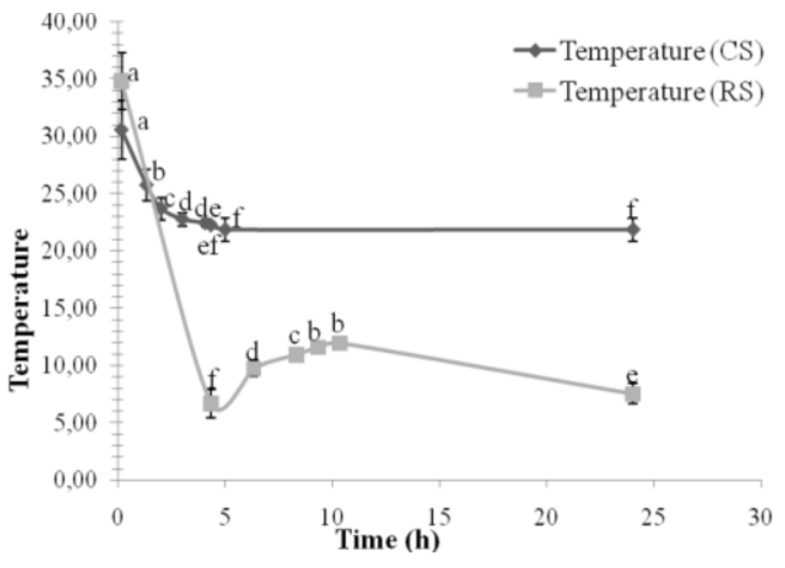

Figure 3 - Temperature (T) values measured firstly in the carcass and subsequently in the breast meat samples held at $0.18 \mathrm{~h}, 1.35 \mathrm{~h}, 2.02 \mathrm{~h}$, $3.02 \mathrm{~h}, 4.08 \mathrm{~h}, 4.35 \mathrm{~h}, 5.02 \mathrm{~h}$ and $24.02 \mathrm{~h}$ $\mathrm{PM}$ aging in control samples (CS) and at $0.18 \mathrm{~h}, 4.35 \mathrm{~h}, 6.35 \mathrm{~h}, 8.35 \mathrm{~h}, 9.35 \mathrm{~h}, 10.35$ $\mathrm{h}$ and $24.02 \mathrm{~h}$ PM aging in refrigerated samples (RS). Means (n =100). ${ }^{\text {a-e }}$ significant different by Tukey test $(\mathrm{p}<0.05)$ among post mortem time in the same treatment.

Color is an important attribute for customer satisfaction at time of purchase (Droval et al. 2012). The $L^{*}$ value of the meat depends on the amount of light scattered. Swatland (1993) reported that an increased scattering of light due to denaturation of sarcoplasmic proteins and an increase in extracellular water were responsible for paler meat. In this experiment, as shown in Table 1 , we followed the $\mathrm{L}^{*}$ values in CS remained dark color with the value of $48.01( \pm 2.33)$ in samples 24.02 h PM and PSE meat was not detected, while for RS, the value for the same time was significantly higher $53.26( \pm 1.89)$ and occurrence of PSE meat was $30 \%$ significantly different by Chi squared test $\left(\chi^{2}\right)(p<0.05)$.

Table 1 - Values of $\mathrm{pH}$, color $\left(\mathrm{L}^{*}\right)$ and PSE meat incidence for control samples (CS) and refrigerated samples (RS) measured at $24.02 \mathrm{~h}$ post mortem

\begin{tabular}{cccc}
\hline Group & $\mathrm{pH}$ & Color L* & PSE incidence (\%) \\
Samples & $(24.02 \mathrm{~h} \mathrm{PM})^{*}$ & $(24.02 \mathrm{~h} \mathrm{PM})^{*}$ & $(24.02 \mathrm{PM})^{* *}$ \\
\hline CS & $5.88^{\mathrm{a}}( \pm 0.14)$ & $48.01^{\mathrm{b}}( \pm 2.33)$ & $0^{\mathrm{b}}$ \\
RS & $5.83^{\mathrm{b}}( \pm 0.16)$ & $53.26^{\mathrm{a}}( \pm 1.89)$ & $30^{\mathrm{a}}$ \\
\hline
\end{tabular}

*Means followed by different letters in the same column differ by Student's t test $(\mathrm{p}<0.05)$.

**Means followed by different letters in the same column differ by Chi Squared test $\left(\chi^{2}\right)(\mathrm{p}<0.05)$.

\section{DISCUSSION}

Studies by Olivo et al. (2001) demonstrated previously, in an experiment carried out at $23^{\circ} \mathrm{C}$, the breast meat samples from the stress broiler chicken group presented a $\mathrm{pHu}$ value lower than 5.7 within 15 min post mortem, and they realized that, under this condition, PSE chicken meat was developed. Glycolysis completion, in this case, lasted only 10-15.0 min, being the initial $\mathrm{pH}$ value of 6.04 and the pHu value was 5.5. Conversely, samples from the unstressed birds group displayed a higher initial $\mathrm{pH}$ value of 6.25 and glycolysis completion was relatively slow, reaching the final $\mathrm{pH}$ value of 5.65 after approximately $30 \mathrm{~min}$. Stressed birds groups displayed completion of rigor mortis twice as fast as unstressed chicken under similar temperature.

Under commercial conditions, as in this experiment, the relevance of temperature towards the glycolysis onset and the final $\mathrm{pH}$ values were determinant for the ultimate $\mathrm{pH}$, and consequently, for PSE development. The gradual decrease of $\mathrm{pH}$ values from neutral $\mathrm{pH}$ values (Fig. 2) took about $4.02 \mathrm{~h}$ in $\mathrm{CS}$ and $8.35 \mathrm{~h}$ in $\mathrm{RS}$ to enter the $\mathrm{pHu}$ value, as illustrated in Figure 2. According to Sams (2001), when the animal dies, the cells gradually switch from aerobic to anaerobic metabolism. The production of lactic acid, the end product of this form of metabolism, also occurs with increased anaerobic activity, and accumulates in the muscle cells of the dead animal. This causes the $\mathrm{pH}$ to decrease near neutrality to an acidic $\mathrm{pH}$ of about 5.7, and reduces the activity of some of the ATP-producing enzymes, further reducing the production of ATP. In our study, the CS group reached the $\mathrm{pHu}$ value much earlier than the RS group, in the period of $4.08 \mathrm{~h}$ PM under carcass T of $23.43^{\circ} \mathrm{C} \pm 0.35$, while $\mathrm{RS}$ group showed a $\mathrm{pHu}$ value in the period of $8.35 \mathrm{~h}$ PM below a $\mathrm{T}$ value of $10.98^{\circ} \mathrm{C} \pm 0.42$. Zhu et al. (2011) found that broiler samples submitted to early post mortem temperature of $40^{\circ} \mathrm{C}$ almost reached the $\mathrm{pHu}$ at $3 \mathrm{~h}$ PM with faster glycolysis compared to the $0^{\circ} \mathrm{C}$ and $20^{\circ} \mathrm{C}$ groups. Other studies have also demonstrated the importance of temperature for the process of glycolysis, which affects meat quality. Earlier reports by Offer (1991), in pigs, reported that myofibril proteins denaturation before rigor is one of the main cause of PSE development, and, as hypothesized by Wilhem et al. (2010), this phenomena may have started even before the birds were slaughtered, while the animals were suffering 
the pre-mortem stress as the PSE meat incidence was observed at the beginning of the refrigeration and quantitatively noticed after the $6.50 \mathrm{~h}$ PM period, as observed in this experiment. Finally, a study carried out by Molette et al. (2003) verified that the $\mathrm{pHu}$ in turkey samples was reached earlier than the other groups using the highest temperature treatment of $40^{\circ} \mathrm{C}$. In our study, the relevant amount of PSE meat was $30 \%$ for the RS group (Table 1). However, contrary to expected, no PSE meat was found in the CS group, indicating that at the $\mathrm{T}$ (from $30.5^{\circ} \mathrm{C}$ to $21.8^{\circ} \mathrm{C}$ ) and $\mathrm{pH}$ (from 6.40 to 5.88) values, throughout the experiment, the meat proteins were not denatured thus keeping their functional properties, unless other unknown factors were present, as reported previously by Van Laack and Lane 2000 and Molette et al. 2003. Moreover, it is important to highlight a recent report by the Betti group (Chan et al. 2011a,b) stating that the refrigeration system can also develop PSE meat as observed in this work. These results demonstrated that the cold temperature plays a significant role in the completion of rigor mortis by delaying the ultimate $\mathrm{pH}$ value. The PSE incidence analyzed after $24.02 \mathrm{~h}$ PM was similar to those found by Simões et al. (2009) and Soares et al. (2003).

\section{CONCLUSIONS}

The results showed retardation of the glycolysis rate promoted by refrigeration treatments. Under these conditions, it seemed that PSE meat formation is induced by refrigeration since this color abnormality is not observed in samples stored under commercial plant room temperature. Thus, it is fair to speculate that PSE meat development depends on multifactorial causes, in particular, on plant processing management, including refrigeration systems. Further research is needed to elucidate the fundamental causes that seem to be related to the biochemical/physiological carcass behavior.

\section{ACKNOWLEDGEMENTS}

The authors would like to thank the financial support granted by PRONEX/Fundação AraucáriaCNPq, Protocol \#09.277. TK held an AT scholarship from CNPq. MRP, FAGC, EII, MS are
CNPq Research Fellows. MS is also under a PVNS-CAPES Scholarship.

\section{REFERENCES}

Alvarado CZ, Sams AR. Turkey carcass chilling and protein denaturation in the development of pale, soft, and exudative meat. Poult Sci. 2004; 83(6): 10391046.

Barbosa CF, Carvalho RH, Rossa A, Soares AL, Coró FAG, Shimokomaki $\mathrm{M}$, et al. Commercial preslaughter blue light ambience for controlling broiler stress and meat qualities. Braz Arch Biol Technol. 2013; 56(5): 817-821.

Barbut S, Sosnicki AA, Lonergan SM, Knapp T, Ciobanu DC, Gatcliffe LJ, et al. Progress in reducing the pale, soft and exudative (PSE) problem in pork and poultry meat. Meat Sci. 2008; 79(1): 46-63.

BRASIL. Ministério da Agricultura, Pecuária e Abastecimento. Departamento de inspeção de produtos de origem animal. Secretaria de defesa agropecuária. Portaria $\mathrm{n}^{\circ} 210$ de 10 de novembro de 1998. Regulamento técnico de inspeção tecnológica e higiênica sanitário de carnes de aves. Diário Oficial da União da República Federativa do Brasil, Brasília, 26 nov. 1998.

Chan JTY, Omana DA, Betti M. Effect of ultimate $\mathrm{pH}$ and freezing on the biochemical properties of proteins in turkey breast meat. Food Chem. 2011a; 127(1): 109-117.

Chan JTY, Omana DA, Betti M. Functional and rheological properties of proteins in frozen turkey breast meat with different ultimate $\mathrm{pH}$. Poult Sci. 2011b; 90(5): 1112-1123.

Droval AA, Benassi VT, Rossa A, Prudencio SH, Paião FG, Shimokomaki M. Consumer attitudes and preferences regarding pale, soft, and exudative broiler breast meat. J Appl Poult Res. 2012; 21(3): 502-507.

James C, Vincent C, Andrade Lima TI, James SJ. The primary chilling of poultry carcass - a review. Int $J$ Refrig. 2006; 29(6): 847-862.

Langer ROS, Simões GS, Soares AL, Oba A, Rossa A, Shimokomaki M, et al. Broiler transportation conditions in a Brazilian commercial line and the occurrence of breast PSE (Pale, Soft, Exudative) meat and DFD-like (Dark, Firm, Dry) meat. Braz Arch Biol Technol. 2010; 53(5): 1161-1167.

Molette C, Rémignon H, Babilé R. Maintaining muscles at a high post-mortem temperature induces PSE-like meat in turkey. Meat Sci. 2003; 63(4): 525532.

Oda SHI, Schneider J, Soares AL, Barbosa DML, Ida EI, Olivo R, et al. Detecção de cor em filés de peito de frango. Rev Nac Carne. 2003; 28(321): 30-34. 
Offer G. Modelling the formation of pale, soft and exudative meats: Effects of chilling regime and rate and extent of glycolysis. Meat Sci. 1991; 30(2): 157184.

Olivo R, Soares AL, Ida EI, Shimokomaki M. Dietary vitamin $\mathrm{E}$ inhibits poultry PSE and improves meat functional properties. J Food Biochem. 2001; 25(4):271-283.

Owens CM, Alvarado CZ, Sams AR. Research developments in pale, soft, and exudative turkey meat in North America. Poult Sci. 2009; 88(7): 1513-1517

Paião FG, Ferracin LM, Pedrão MR, Kato T, Shimokomaki M. Skeletal muscle calcium channel ryanodine and the development of pale, soft, and exudative meat in poultry. Genet Mol Res. 2013; 12(3): 3017-3027.

Sams AR. Second processing: parts, deboning, and portion control. In: Sams AR. Poultry meat Processing. Boca Raton: CRC Press; 2001. p. 39-40.

Simões GS, Oba A, Matsuo T, Rossa A, Shimokomaki M, Ida EI. Vehicle thermal microclimate evaluation during Brazilian summer broiler transport and the occurrence of PSE (Pale, Soft, Exudative) meat. Braz Arch Biol Technol. 2009a; 52: 195-204.

Simões GS, Rossa A, Oba A, Matsuo T, Shimokomaki M, Ida EI. Influência do Transporte em Frangos PSE e a-DFD. Rev Nac Carne. 2009b; 33(383): 20-30.

Soares AL, Lara JAF, Ida EI, Guarnieri PD, Olivo R, Shimokomaki M. Influence of preslaughter handling practices on broiler meat color in a commercial plant. In: 2003 IFT Annual Meeting and Food Expo, 2003, Chicago. 2003 IFT Annual Meeting Book of Abstracts, 2003. p.201.
Sosnicki AA, Greaser ML, Pietrzak M, Pospiech E, Sante V. PSE-like syndrome in breast muscle of domestic turkeys: a review. J Muscle Foods. 1998; 9(1): 13-23.

Swatland H.J. Paleness, softness, and exudation in pork-review. In: Poulanne E, Demeyer DI. Pork Quality: Genetic and Metabolic Factors. Wallingford: C.A.B. International; 1993. p. 273-286.

UBABEF - União Brasileira de Avicultura. Relatório Anual 2013; 2013. 57 p.

Van Laack RL, Lane JL. Denaturation of myofibrillar proteins from chicken as affected by $\mathrm{pH}$, temperature, and adenosine triphosphate concentration. Poult Sci. 2000; 79(1):105-109.

Wilhelm AE, Maganhini MB, Hernández-Blazquez FJ, Ida EI, Shimokomaki M. Protease activity and the ultrastructure of broiler chicken PSE (Pale, Soft, Exudative) meat. Food Chem. 2010; 119(3): 12011204.

Zhu X, Ruusunen M, Gusella M, Zhou G, Puolanne E. High post-mortem temperature combined with rapid glycolysis induces phosphorylase denaturation and produces pale and exudative characteristics in broiler Pectoralis major muscles. Meat Sci. 2011; 89(2): 181188.

Received: May 14, 2014; Accepted: September 27, 2014. 